\title{
Nest Records, Nesting Colony Selection of Oriental White Backed Vulture (Gyps bengalensis) and Role of Feeding Station in Kangra, Himachal Pradesh
}

\author{
Archi Sehgal ${ }^{1 *}$ and Krishan Kumar ${ }^{2}$ \\ ${ }^{1}$ Department of Forestry and Wildlife Sciences, Amity University, Noida, India \\ ${ }^{2}$ Divisional Forest Officer, Shimla, Himachal Pradesh, India \\ *Corresponding Author: Archi Sehgal, Department of Forestry and Wildlife \\ Sciences, Amity University, Noida, India.
}

Received: November 24, 2021

Published: December 16, 2021

(C) All rights are reserved by Archi Sehgal and

Krishan Kumar.

\begin{abstract}
This study aimed to infer nest count for breeding period 2018, identify key variables for nest site selections and understanding the role of distance from feeding station to each nesting colony. The Nest count were conducted during breeding period, each nest categorize into active and inactive nests based on assessment of different components. Simultaneously, different variables (tree height, tree species, elevation and aspect) were recorded for each nest. Aerial distance was used to determine the role of feeding station for selecting nesting colonies. From the 24 nesting colonies, 352 active nests were recorded, and a significant Pearson's correlation for elevation and aspect were drawn. We found, vulture prefer single tree specie for nesting. We also found that, $71 \%$ (n = 17) nesting colonies were located within radial distance of $20 \mathrm{~km}$. The study highlights high congregration of active nests within short radial distance from feeding station which signify the positive impact of management of feeding station by the wildlife wing of Forest department since 2008, for the in-situ conservation of critically endangered Oriental White Backed Vulture (Gyps bengalensis). Keywords: Oriental White Backed Vulture; Gyps bengalensis; India; Nesting colony; Feeding Station
\end{abstract}

\section{Abbreviation}

OWBV: Orirntal White Back Vulture

\section{Introduction}

Among 23 species of vultures, 12 species are currently classified as "Near Threatened" or "Endangered" [1]. In India, 106 Raptor species are found which makes 18 percent of 572 species that are spread all over the world [2,3]. Of these, 8 species of vultures are reported from Himachal Pradesh: Oriental White Backed (OWBV, Gyps bengalensis), Himalayan Griffon (Gyps himalayensis), Eurasian Griffon (Gyps fulvus), Lammergeyer (Gypaetus barbatu), Long Billed Vulture (Gyps indicus), Cinereous (Aegypius monachus), Egyptian (Neophron percnopterus) and Red Headed Vulture (Sarcogyps calvus) [4]. Thirty years ago, the vulture population in Northern-Central India, appeared to be highest in urban areas [5]. The evidence of catastrophic decline reported during the late 1990's from Keoladeo National Park, Rajasthan [6]. Various hypotheses were put forward to investigate the cause for this rapid decline [79]. Later it was discovered, a non-steroidal anti-inflammatory drug
(NSAID): diclofenac was the main causative factor for rapid population decline across the Indian subcontinent [9]. OWBV is one of four Critically Endangered species of vultures in India, others are Gyps indicus, Gyps tenuirostris, Sacrogyps calvus $[6,7,10]$.

OWBV is the smallest among Gyps species, feed exclusively on carrion, they are gregarious and social, they forage in flocks, roost and nest in colonies [11]. They breed and nest from October-April. Pairs are monogamous, raise one nestling per year, the incubation period is approximately 50-56 days, the nestling period lasts approximately 104 days [12-14]. This species is known to show partial migration that ranges from $1000-2000 \mathrm{~km}^{2}$ and sometimes across the borders between Nepal and India $[15,16]$.

Their population has drastically affected in the last decade as a result of several factors -the use of diclofenac, shortage of food and electrocution. Thus, to conserve the breeding population, it is important to safeguard their nesting habitats which vary in spatial scale and it has been reported for other vulture species that the establishment of feeding stations can significantly increase the 
Nest Records, Nesting Colony Selection of Oriental White Backed Vulture (Gyps bengalensis) and Role of Feeding Station in Kangra, Himachal Pradesh

survival of first-year vultures [17] and can also affect the growth in nesting colonies as seen in California Condor [18]. The present study aimed to identify nesting sites of OWBV and determine nest site variables such as aspect of the nest, elevation, the height of nesting tree. Also, to investigate the role of feeding stations, which has been established as a species-specific conservation measure by Forest department of Himachal Pradesh.

\section{Methods}

Study area

This study was carried out in the Kangra district of Himachal Pradesh. This district is traversed by varying altitudes of Shivalik's, Dhauladhar and Himalayas from northwest to southeast. The altitude varies from $500 \mathrm{~m}$ above mean sea level to around $5000 \mathrm{~m}$ above the mean sea level. The climate of the district varies from sub-tropical in lower hills and valleys to sub-humid in the mid-hills and gets temperate in high hills. The forest cover of Kangra district includes $297 \mathrm{~km}^{2}$ area as a very dense forest and $1279 \mathrm{~km}^{2}$ as moderate dense forest [19]. We carried out nest survey within the boundary of our study area with the help of Forest staff (Figure 1). We also relied on the knowledge and experience of the locals for tracing nests. We visited the feeding station located in Nagrota Surian village of Kangra district, constructed in an open land area of $100 \mathrm{~m} \mathrm{X} 100 \mathrm{~m}$. It is fenced to exclude facultative scavengers and maintained by Forest department since 2008. The dead livestock comes from nearby villages, which is transported by members of a particular community called 'MOOCHIS' to the feeding station.

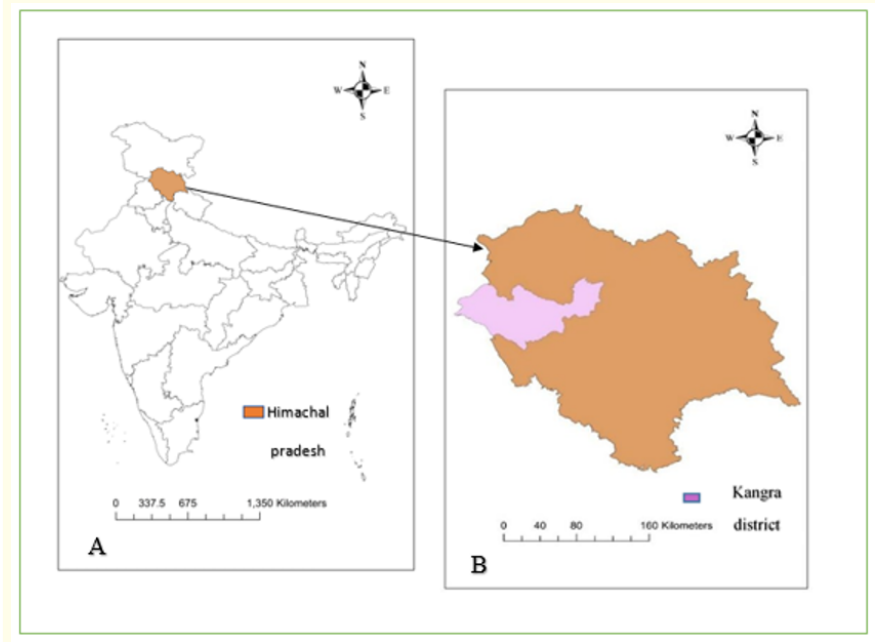

Figure 1: Map of study area: (A) highlights the state of Himachal Pradesh, (B) marks the Kangra district within Himachal Pradesh.

\section{Data collection}

Nest records

The nest survey was carried out during the hatching and fledgling period of OWBV from January 2018 to April 2018 with the help of forest department. The prior reports of forest department recorded the total 48 nesting colonies in the same district however some of these nesting colonies were abandoned by OWBV over the years, we scanned all the 48 nesting colonies which were previously identified and regularly monitored during the breeding season in different beats and ranges of forest in Kangra. To categorize individual nest as "active nests" we look for the presence of one of the parents, fresh droppings and sights of a fledgling. However, it was relatively easy to identify "inactive nest" as there were no parents, fledglings and any fresh droppings [20,21]. Each nest was observed using Olympus binocular $50 \times 100$ from a distance to identify it as an active or inactive nest. We considered "beat" a unit of nesting colony, those beats having at least 1 active nest taken as "active nesting colony". While beats with zero active nests were recorded as "inactive nesting colony". Each nesting colony was extensively surveyed on foot, observations were recorded for each nest and to avoid duplication we followed the unidirectional movement.

\section{Nest site variable}

At each nest we recorded the various variables (Table 1), these are selected based on literature $[14,22,23]$. We recorded GPS coordinates, the height of nesting tree, elevation and aspect of the nest. To determine the height of nesting tree we use a clinometer. To record the elevation, we took the reading of each the nests using Garmin eTrex GPS handset and for aspect we used DEM map in ArcGIS 10.3. using each nest's GPS coordinates. We also recorded tree species on which nest was build.

\begin{tabular}{|l|c|}
\hline Nest site variables & Measurement Unit \\
\hline $\begin{array}{l}\text { Tree species } \\
\text { Height of each nesting tree }\end{array}$ & $\begin{array}{c}\text { At specie level } \\
\text { Measured in meters(m) }\end{array}$ \\
\hline Elevation of each nest & Measured in meters(m) \\
\hline Aspect of nest & $\begin{array}{c}\text { Measured in degree (North- } 0^{\circ}, \\
\text { East- } 90^{\circ}, \text { South- } 180^{\circ}, \text { West- } 270^{\circ}\end{array}$ \\
\hline
\end{tabular}

Table 1: Description of Nest variables.

\section{Feeding station}

To determine the role of feeding station in the selection of nesting colony by OWBV, we use the Garmin eTrex GPS handset to re- 
cord GPS location of feeding station and each nesting colony. We tried to establish link between the ratio of inactive nest to active nest at each nesting colony with the distance from the feeding station. The aerial distance was calculated using Google Earth Pro. Also, we calculated the number of nesting colonies falling in the radial distance of $10 \mathrm{~km}, 20 \mathrm{~km}$ and $30 \mathrm{~km}$ through the same method.

\section{Statistical analysis}

We listed all active and inactive nest found at each nesting colony. The Nesting colony are classified as "active nesting colony" and "inactive nesting colony" based on the number of active nests recorded within it. We used Pearson's correlation to identify variables that are correlated with the nesting colony selection. We consider each nest as a sample unit for the analysis. This study also looked at the role of feeding station in the nesting colony selection. Thus, each nesting colony were taken as unit of analysis for the spearman's rank correlation, the ratio of inactive to active nest at each nesting colony was correlated with the distance to the feeding station [24].

\section{Results}

\section{Nest record}

Total 387 nests of Critically Endangered OWBV were recorded of which 352 were active with fledglings. figure 2 , shows 24 active nesting colonies having at least 1 active OWBV nests. From the (Table 2), the lowest number of nests was recorded from 'Bassa' ( $\mathrm{n}=$ 2 ), situated next to the roadside. While the highest number of nests recorded at 'Pathiar' site $(\mathrm{n}=43)$, located in a dense forest area.

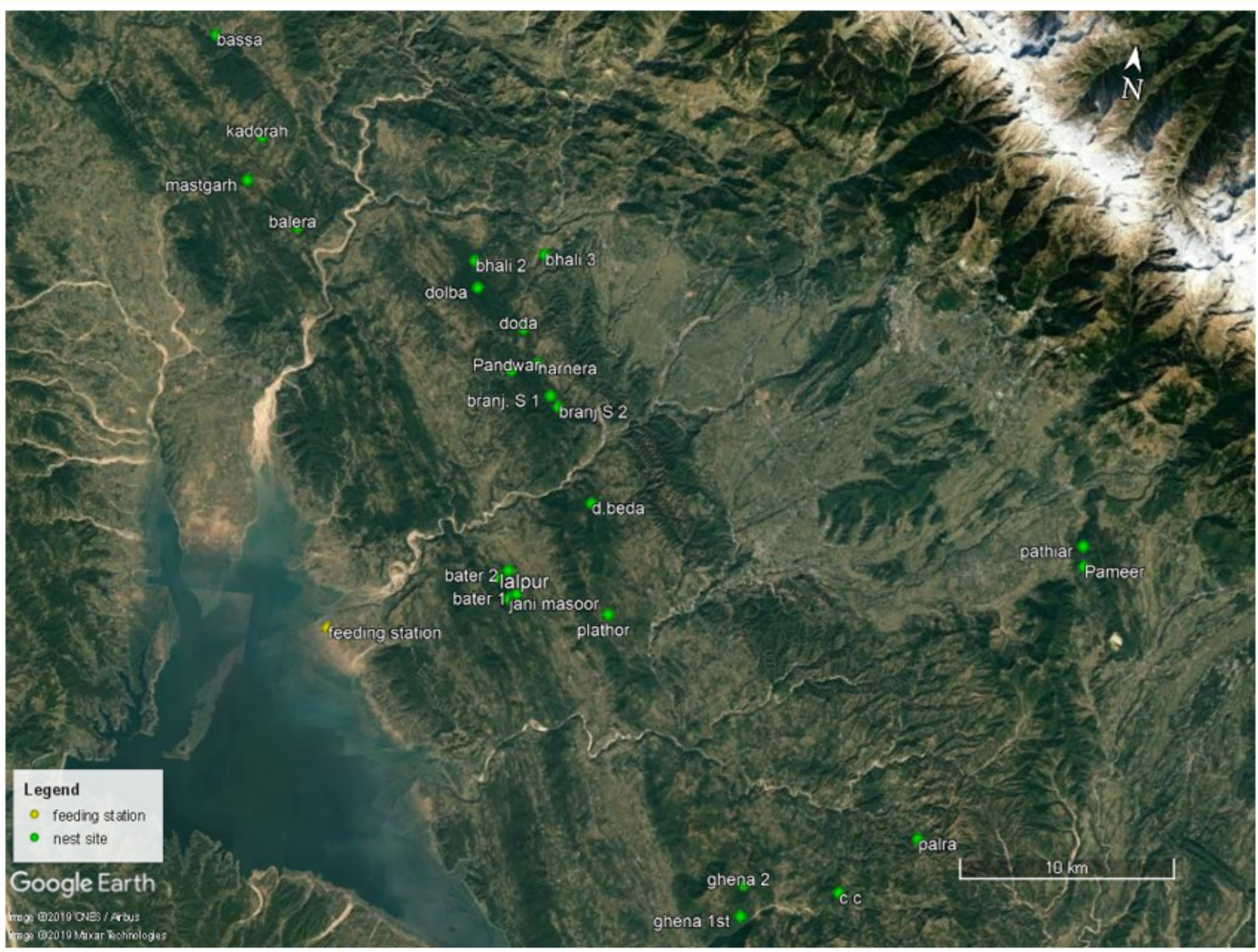

Figure 2: GPS location of 24 active nesting colonies of OWBV, marked with green dots and Feeding station highlighted with yellow dot. 
Nest Records, Nesting Colony Selection of Oriental White Backed Vulture (Gyps bengalensis) and Role of Feeding Station in Kangra, Himachal Pradesh

\begin{tabular}{|l|c|c|c|c|}
\hline $\begin{array}{l}\text { Nesting } \\
\text { site }\end{array}$ & $\begin{array}{c}\text { Name of } \\
\text { Nesting } \\
\text { colonies }\end{array}$ & $\begin{array}{c}\text { Total } \\
\text { number } \\
\text { of nests } \\
\text { recorded }\end{array}$ & $\begin{array}{c}\text { Number of } \\
\text { fledglings }\end{array}$ & $\begin{array}{c}\text { Aerial distance } \\
\text { with respect to } \\
\text { Feeding station } \\
\text { (km) }\end{array}$ \\
\hline 1 & Bater 1 $^{\text {st }}$ & 19 & 16 & 8.94 \\
\hline 2 & Bater 2 $^{\text {st }}$ & 6 & 4 & 8.92 \\
\hline 3 & Jani Masoor & 30 & 27 & 8.55 \\
\hline 4 & Branj s. ${ }^{\text {st }}$ & 15 & 13 & 14.96 \\
\hline 5 & Branj s. $2^{\text {nd }}$ & 17 & 15 & 14.94 \\
\hline 6 & Harnera & 4 & 4 & 15.68 \\
\hline 7 & Pandwar & 24 & 22 & 14.72 \\
\hline 8 & C.C & 26 & 24 & 26.78 \\
\hline 9 & Pameer & 7 & 7 & 35.3 \\
\hline 10 & Bhali 2 & 6 & 6 & 18.39 \\
\hline 11 & Mastgarh & 13 & 12 & 21.37 \\
\hline 12 & Kadroah & 30 & 26 & 23.21 \\
\hline 13 & Lalpur & 40 & 38 & 8.33 \\
\hline 14 & Doda & 5 & 4 & 16.61 \\
\hline 15 & Palra & 15 & 14 & 29.21 \\
\hline 16 & Ghena $1^{\text {st }}$ & 11 & 10 & 23.41 \\
\hline 17 & Pathiar & 45 & 43 & 35.28 \\
\hline 18 & Bhali $3^{\text {rd }}$ & 16 & 15 & 20.3 \\
\hline 19 & Dolba & 25 & 22 & 17.22 \\
\hline 20 & Balera & 9 & 9 & 18.81 \\
\hline 21 & Gheena 2 & 3 & 3 & 22.73 \\
\hline 22 & Bassa & 2 & 2 & 28.21 \\
\hline 23 & D. beda & 15 & 12 & 13.61 \\
\hline Plathore & 4 & 4 & 13.9 \\
\hline
\end{tabular}

Table 2: Description of 24 active nesting colonies with total nest and active nest with fledgling found at each site, also described the distance between nesting colony and feeding station is given.

\section{Nest site variable}

We found a significant correlation between elevation and nests i.e., greater number of nests falls within average elevation of $671 \pm$ $68 \mathrm{~m}$ (Pearson's correlation, $\mathrm{r}=0.526, \mathrm{P}<.0001$ ). When calculating correlation between aspect and nests: we found a significant correlation (Pearson's correlation, $\mathrm{r}=.154, \mathrm{P}<.0007$ ). OWBV prefers nesting colony more towards the south $(22 \%, n=78)$, south-west $(17 \%, \mathrm{n}=60)$ and north $(18 \%, \mathrm{n}=68)$ and few nesting colonies in east $(5 \% n=18)$, north-east $(8 \% n=29)$, northwest $(4 \% n=17)$

\section{Discussion}

\section{Nest record}

The present study depicts the Kangra district of Himachal Pradesh as a potential site for the in-situ conservation of Critically Endangered OWBV, it support 352 active nests for the breeding season of 2018-19. Similarly, 19 active nesting colony were reported 
Nest Records, Nesting Colony Selection of Oriental White Backed Vulture (Gyps bengalensis) and Role of Feeding Station in Kangra, Himachal Pradesh

within the present study area for the breeding season of 2009-2011 [22]. We assumed, some critical ecological factors supporting highly concentrated breeding population in low laying Shivalik's hills of the Kangra district. The awareness among people for the diclofenac drug and its low to no use around nesting colony promoted the conservation efforts in a positive direction along with Forest department [22].

\section{Nest site variable}

The results highlighted that selection of nest site is influenced by two important variables- elevation and the aspect. While the height of nesting tree was not an important variable for nest-site selection probably because the preference for nesting tree height varies greatly at spatial scale. OWBV was reported to build nest as low as 4 to $5 \mathrm{~m}$ where large trees are absent [3]. Similar observations were reported from Gujarat with an average tree height of $16.4 \mathrm{~m}$ [25]. Thus, we predict OWBV are flexible for selecting of nesting tree height accordingly to the topography of the local region. We found OWBV prefer an average elevation of $671 \pm 68 \mathrm{~m}$, they are known to restrict their nesting to low-land areas $[3,26]$. Pinus roxburghii mostly occur in lower Shivalik's of Kangra district from the elevation between $450 \mathrm{~m}$ to $1050 \mathrm{~m}$. OWBV using these pine trees at this elevation due to the absence of other dominant tree species with an average height of $20.8 \mathrm{~m}$. Also, we found vultures prefer nest building facing mostly in south and north direction. Similar observation was reported from the Mayor valley of Tamil Nadu for the same species. This protects them from inclement conditions like directional movement of cold winds or direct solar radiation and facilitated them to raise their body temperature after nocturnal dip [27].

\section{Feeding station}

Studies supported that feeding stations can facilitate the recolonization of scavenging raptors [28,29]. Similarly, it was found that all nesting colonies were located at an average aerial distance of $19.14 \pm 7.78 \mathrm{~km}$ from the feeding station, probably because the proximity of feeding station can reduce foraging time and also the availability of food at feeding station can reduces the risk of mortality [18]. We found, an increase in active nesting colonies as well as the active nests number as compared to previous studied within same study area.

Feeding station play a significant role in subsequent slight population recovery, as reported in long-billed vulture [12,30] and for California Condor [18] and can also improves the reproductive success and survival of first-year juveniles [17, 31,32].

\section{Conclusion}

Dedicated efforts of the wildlife wing HP Forest Department, regular monitoring of the nesting colonies and zero prevalence of diclofenac can be the reasons of thriving good population of Critically Endangered OWBV in that region. The Pong dam and its surrounding areas of 19 nesting colonies holds good potential to be declared as Vulture Conservation Reserve in future to protect its Natural breeding habitat.

\section{Acknowledgments}

Special thanks to H.P. Forest Department (Wildlife wing) for all logistics and support. We thank the Department of Forestry and Wildlife, Amity University for providing us technical support throughout the study.

\section{Bibliography}

1. https://wwwa.iucn.org/sites/dev/files/content/documents/ vulture_symposium_proceedings_2016.pdf

2. Ali Salim and Sidney Dillon Ripley. "Handbook of the birds of India and Pakistan" (1983).

3. Naoroji Rishad and N John Schmitt. Birds of prey of the Indian subcontinent. Om Books International, (2007).

4. Puri Kanchan., et al. "Abundance of vultures in Shivalik foothills of north west India". International Journal of Science and Environment 7 (2018): 1750-1754.

5. Galushin Vladimir M. "A huge urban population of birds of prey in Delhi India”. Ibis 113.4 (1971): 522-522.

6. Prakash Vibhu. "Status of vultures in Keoladeo National Park, Bharatpur, Rajasthan, with special reference to population crash in Gyps species". Journal Bombay Natural History Society 96 (1999): 365-378.

7. Pain Deborah J., et al. "Causes and effects of temporospatial declines of Gyps vultures in Asia". Conservation Biology 17.3 (2003): 661-671.

8. Prakash, Vibhu, et al. "Catastrophic collapse of Indian whitebacked Gyps bengalensis and long-billed Gyps indicus vulture populations". Biological conservation 109.3 (2003): 381-390.

9. Oaks J Lindsay., et al. "Diclofenac residues as the cause of vulture population decline in Pakistan". Nature 427.6975 (2004): 630-633.

10. Green Rhys E., et al. "Rate of decline of the oriental whitebacked vulture population in India estimated from a survey of diclofenac residues in carcasses of ungulates". PLoS One 2.8 (2007): e686. 
Nest Records, Nesting Colony Selection of Oriental White Backed Vulture (Gyps bengalensis) and Role of Feeding Station in Kangra, Himachal Pradesh

11. Sharma, Indra Kumar. "Breeding of the Indian Whitebacked Vulture at Jodhpur”. Ostrich 41.3 (1970): 205-207.

12. Gilbert Martin., et al. "Breeding and mortality of oriental white-backed vulture Gyps bengalensis in Punjab Province, Pakistan". Bird Conservation International 12.4 (2002): 311326.

13. Thakur M L. "Breeding ecology and distribution of Whiterumped Vultures (Gyps bengalensis) in Himachal Pradesh, India”. Journal of Raptor Research 49.2 (2015): 183-191.

14. Baral N A B I N., et al. "Population status and breeding ecology of White-rumped Vulture Gyps bengalensis in Rampur Valley, Nepal". Forktail 21 (2005): 87.

15. Clements Tom., et al. "Vultures in Cambodia: population, threats and conservation". Bird Conservation International 23.1 (2013): 7-24.

16. Ferguson-Lees James. "Raptors of the world: an identification guide to the birds of prey of the world". (2001).

17. Piper Steven E., et al. "Modelling survival rates in the Cape Griffon Gyps coprotheres, with emphasis on the effects of supplementary feeding". Bird Study 46.1 (1999): S230-S238.

18. Snyder Noel FR and Helen A Snyder. "Introduction to the California condor”. Univ of California Press 81 (2005).

19. Forest survey of India. "State of forest report". Ministry of Environment and Forest, Dehradun, India (2017).

20. Haines Dawn E and Kenneth H Pollock. "Estimating the number of active and successful bald eagle nests: an application of the dual frame method". Environmental and Ecological Statistics 5.3 (1998): 245-256.

21. Chomba Chansa and Eneya M'Simuko. "Nesting patterns of raptors; White backed vulture (Gyps africanus) and African fish eagle (Haliaeetus vocifer), in Lochinvar National Park on the kafue flats, Zambia". Open Journal of Ecology 3.5 (2013): 325.

22. Thakur M L and S K Narang. "Population status and habitat-use pattern of Indian White-backed Vulture (Gyps bengalensis) in Himachal Pradesh, India". Journal of Ecology and the Natural Environment 4.7 (2012): 173-180.

23. Freund Myriam., et al. "Breeding Success and its Correlation with Nest-Site Characteristics: A Study of a Griffon Vulture Colony in Gamla, Israel". Journal of Raptor Research 51.2 (2017): 136-144.
24. Vlachos Christos G., et al. "Effects of the feeding station establishment on the Egyptian Vulture Neophron percnopterus in Dadia Forest, North Eastern Greece". RD Chancellor, B.-U. and Meyburg and JJ Ferrero, eds. Holarctic birds of prey, Proceedings of an international conference. Mérida and Berlin: ADENEX-WWGBP 197 (1998).

25. Gadhvi I R., et al. "Indian White-backed Vultures Gyps bengalensis nesting in Mahuva, Bhavnagar district, Gujarat, India". Indian Birds 2.2 (2006): 36.

26. Giri Jeet Bahadur and S GC. "Study of vultures in western lowland Nepal”. Oriental Bird Club Bulletin 36 (2002): 11-13.

27. Venkitachalam $\mathrm{R}$ and S Senthilnathan. "Breeding Record of Indian Vulture (Gyps indicus) in Moyar Valley, Tamil Nadu, India". Current science 109.2 (2015): 258-259.

28. Oro Daniel., et al. "Testing the goodness of supplementary feeding to enhance population viability in an endangered vulture". PloS one 3.12 (2008): e4084.

29. Lieury Nicolas., et al. "Relative contribution of local demography and immigration in the recovery of a geographically-isolated population of the endangered Egyptian vulture". Biological Conservation 191 (2015): 349-356.

30. Balmford Andrew. "Pollution, politics, and vultures". Science 339.6120 (2013): 653-654.

31. Grande Juan M., et al. "Survival in a long-lived territorial migrant: effects of life-history traits and ecological conditions in wintering and breeding areas". Oikos 118.4 (2009): 580-590.

32. Margalida Antoni., et al. "Factors influencing the breeding density of Bearded vultures, Egyptian vultures and Eurasian griffon vultures in Catalonia (NE Spain): management implications". Animal Biodiversity and Conservation 30.2 (2007): 189-200.

\section{Assets from publication with us}

- Prompt Acknowledgement after receiving the article

- Thorough Double blinded peer review

- Rapid Publication

- Issue of Publication Certificate

- High visibility of your Published work

Website: www.actascientific.com/

Submit Article: www.actascientific.com/submission.php

Email us: editor@actascientific.com

Contact us: +919182824667 